\title{
Archivally Absent? Female Filmmakers in the IFI Irish Film Archive
}

\section{Kasandra O'Connell}

\begin{abstract}
This paper is an initial exploration of women's contribution to collections of the IFI Irish Film Archive, specifically in the area of amateur film production. It considers two female-created collections in this sphere of practice, the Currivan and Overend Collections, examining the context in which they were created as well as the nature of the films themselves. This article also examines the reasons why women are underrepresented in film production, specifically the extent to which organisational policies and the gendered nature of leadership and employment effect what material is produced and preserved. It concludes by looking at praxis within the IFI Irish Film Archive collections and asking what measures the Irish Film Institute can adopt to improve women's representation and visibility in its programmes of exhibition and preservation.
\end{abstract}

This paper is an initial exploration of women's contribution to the material held within the collections of the Irish Film Institute's Irish Film Archive (IFI Archive). ${ }^{1}$ In recent years there has been an increased awareness of the work of female filmmakers and the need for them to have greater representation within the professional production sector (Liddy, Where). While this increased focus on work created by women is welcome it tends to overlook the output of those operating outside the commercial realm. As a result, little has been written about women's amateur filmmaking in Ireland, something this article aims to address by considering two collections in the IFI Archive created by women in this sphere of practice. ${ }^{2}$ This article will, as such, examine the extent to which organisational policies and the gendered nature of leadership and employment effect what films are produced and preserved in the first instance. It then examines the context in which women's amateur film collections were created as well as the nature of the films themselves and concludes by considering what measures can be adopted by the IFI Archive and its parent organisation, the Irish Film Institute, to improve women's representation and visibility, despite the historic undervaluing of female authored work (even by its creators). Ultimately, this article will shine a light on the mostly hidden, but nonetheless significant, contribution of women in creating material within the IFI Archive collections, particularly work classified as nonprofessional.

\section{Context for the Analysis}

My interest in the often-overlooked place of women in the arts developed during my MA in Museum Studies at the University of Leicester. My dissertation focused on the contribution made by women to the development of the visual arts sector in Ireland during the twentieth century. ${ }^{3}$ It focused primarily on their involvement as practitioners, patrons and institutional staff and discovered a history of marginalisation, with the contribution of female professional staff largely ignored, and only a handful of women artists represented within national collections prior to the opening of the Irish Museum of Modern Art (IMMA) in 1991. 
Subsequently, on commencing my position as Head of the IFI Irish Film Archive in 2000, I was eager to discover whether the audio-visual sector mirrored the poor gender ratios I had encountered elsewhere in the arts. My initial impressions of the position of women within the Irish film industry were encouraging as I began my tenure at the IFI, Ireland's national cultural institution for film, under the stewardship of a female director and a female chair. ${ }^{4}$ However, a deeper inspection of the material preserved in the national collection revealed a less equitable picture, one that mirrored the reality of the global film industry in its lack of female voices.

\section{Reclaiming Contributions}

In recent decades, a dynamic movement to excavate and promote women's contribution to cinema has evolved as a reaction to their long-standing and widespread exclusion from film history. Organisations such as Women in Film and Television (both in Ireland and internationally), the Women's Film \& Television History Network (UK/Ireland) and projects such as Women Film Pioneers (US) have endeavoured to reinsert women into the history of filmmaking. Equally, scholars such as Christine Gledhill, Julia Knight, Shelley Stamp, Jane Gaines, and Jennifer M. Bean and Diane Negra have provided compelling evidence of the significant role played by women in the silent era and beyond, while in Ireland, the position of women in Irish cinema has been interrogated by researchers such as Donna Casella, Ruth Barton ("A Female Voice"; "Irish Cinema"), Maeve Connolly ("Choreographing"; "Feminism"; "Women") and, in this issue of Alphaville, Veronica Johnson, amongst others.

As a cultural climate challenging gender disparity in the Irish arts has emerged in recent years, the level of women's involvement in the professional production sector has come under increased scrutiny. While this overdue interest in commercial female filmmakers is welcome, it should be noted that the same level of examination has not been afforded to noncommercial filmmaking; something this article seeks to rectify.

\section{Cultural and Labour Landscape}

Despite a radical shift in societal structures in the post-war period, and the emergence of a more intersectional social and political discourse, most cultural collections remain characterised by a white, male middle-class viewpoint (Topaz). Consequently, the concerns of women and other minority groups are marginalised, and those groups classified by their otherness. A predominance of men within the labour market and more importantly in positions of seniority is likely to have influenced this cultural bias. Therefore, before moving on to examine specific collections held in the IFI Archive, I feel it is worth exploring the employment landscape in which the Irish film industry operates to see if this explains why women's creative output and artistic concerns have been so often overlooked.

The 2017 gender pay gap report No Small Change by the National Council for Women indicates that the arts is one of the lowest paid sectors in Ireland and that it has an overrepresentation of women in part-time and voluntary positions (21). Similarly, a 2013 report by the European Institute for Gender Equality found that women occupy just 16\% of high-level decision-making positions in EU media organisations and cited Ireland as one of the countries with the poorest record of female leadership (Advancing 8). This lack of female representation in positions of influence and women's predominance in less senior and less secure forms of 
employment has undoubtedly contributed to the disempowerment of women within the arts in Ireland.

Although these statistics are bleak there is some cause for optimism, as there has been a notable improvement in the leadership profile of the Irish cultural arena in recent years, with senior roles that had traditionally been dominated by men increasingly held by women. For example, six of the eight Irish national cultural institutions currently have female directors, and several state arts funding agencies are also now led by women. ${ }^{5}$ It is hoped that this new era of female leadership within the Irish arts will result in more inclusive institutional policies, leading to more democratic and representative exhibition and preservation programmes. I believe these promising signs of change in the arts were made possible by recent high-profile challenges to gender disparity in the Irish cultural sector.

One such challenge, Waking the Feminists, is considered by many to have been one of the catalysts for a new wave of feminist activism in the arts (Healion, et al. 153; Liddy, "Open"; O'Brien, Women). This grassroots campaign evolved largely on social media in 2015 following vocal criticism by designer and arts manager Lian Bell of the absence of women playwrights in the Abbey Theatre's 2016 centenary programme (Mullally). The organisation's then director Fiach Mac Conghail's initially dismissive response to the criticism resulted in a furore that focused attention on the gender disparity in the theatrical sphere (Keating). The subsequent media attention prompted a broader conversation that questioned discrimination in other Irish arts organisations and cultural sectors (Liddy, "Missing"; "Women"), thus provoking a reassessment of women's representation and an examination of their exclusion from management and lead creative roles. This attention to, and criticism of, discrimination has led to a number of positive developments in the cultural sector, and film industry initiatives include the gender parity and inclusion pledge signed by eight Irish film festivals in May 2019 under the stewardship of Women in Film and Television Ireland, and the establishment of the Dublin Feminist Film Festival in 2014. ${ }^{6}$

The IFI has also introduced a range of gender initiatives as a result of these debates. These include the adoption of the F-Rating in 2018 to highlight films written or directed by women; the provision of a forum for the discussion of gender representation as part of Spotlight, the IFI's annual industry day (2016-2020); female focused programming strands such as the Ida Lupino (2018) and Dorothy Arzner (2019) seasons, and the Pat Murphy (2012), Vivienne Dick (2017) and Trish McAdam (2019) retrospectives; several collaborations with Women in Film and Television, and preservation and programming projects focusing on women's work. ${ }^{7}$ In implementing these measures to highlight women's creative output the IFI has been conscious to strike a balance between emphasising female production and ghettoising it and, as a result, has endeavoured to make these initiatives part of the main exhibition programme where possible. ${ }^{8}$

The high-profile debates around gender in the arts have been augmented by academics such as Susan Liddy ("Missing"; "Open"; "Setting"; "Where") and Anne O'Brien ("Men"; "Producing"; "Feminine"), who provided empirical evidence for inequity within the media and film sector. Their quantitative and qualitative data demonstrated the inherent bias that existed across funding, commissioning, and other power structures, providing the ammunition necessary to challenge the industries' gender status quo. This sectoral evidence and the broader public discourse regarding women's lack of parity within the arts prompted state agencies such as Screen Ireland (SI), the Broadcasting Authority of Ireland (BAI) and the Arts Council (AC) to directly address the issue through policy, with SI developing a Six Point Plan on Gender 
Equality (2015), the BAI a Gender Action Plan (2018) and the AC an Equality, Human Rights and Diversity (EHRD) Policy and Strategy (2019). ${ }^{9}$

\section{The Impact of Gender Policy}

The introduction of these gender strategies within the Irish production sector will have a direct impact on female representation within the content preserved by the IFI Archive due to its relationship with these funding bodies. As custodian of the national moving image collection, the IFI has ongoing agreements with all three agencies-SI, BAI and AC-to preserve productions they fund, thus ensuring the existence of a comprehensive collection of state financed content. Consequently, changes in the themes of projects that receive funding, or in the gender ratios of key production staff, will ultimately be reflected in the material preserved by the IFI on behalf of these organisations.

Although historically women have held a minority of lead roles in projects supported by these state agencies, it now appears that female representation behind the camera is slowly beginning to improve, in part due to these new gender initiatives. According to SI, for the period 2010 to 2015 , only $16 \%$ of funding applications to that organisation had female writers attached, 14\% had female directors and 36\% had female producers (Six Point Plan). However, these figures had dramatically improved by 2019, with 69 of projects having a female producer, $43 \%$ a female writer and 37\% a female director according to the Screen Ireland report on gender statistics in production and development (2019). Similarly, the BAI reports that in its most recent Sound \& Vision Funding Scheme, more than $80 \%$ of funded television projects identified between one and four women in lead creative roles (2020).

Although these figures are enlightening, they only present a partial picture of the material being acquired for the national moving image collection, as they focus exclusively on professionally made film. Classifying moving image material by its professional or amateur status is a standard mechanism employed by film archives and consequently the IFI Archive collections can be broadly divided into these two groupings, with $71 \%$ of the catalogued collection identified as professional and $29 \%$ as nonprofessional. While there has recently been some interest in the number of female filmmakers represented in the professional collections, the gender ratio that exists in the category of amateur film has been largely ignored. For this reason, I would like to spend a little time exploring female representation in the underresearched area of amateur film production.

\section{Amateur Collections}

As historians in the contemporary era became concerned with the marginalised and underrepresented, they began to broaden their research to include those who had been largely ignored in official historical narratives. The academic study of amateur films and filmmaking is a relatively recent field of inquiry, emerging from this wider move within historiography to counter the actions of historians and archivists in reinforcing cultural and social stereotypes. Described by Annamaria Motrescu-Mayes and Heather Norris Nicholson "as the recreational making and interpretation of films for personal and wider non-commercial use" (2), amateur production became increasingly studied from the 1990s onwards with monographs on the subject from academics such as Patricia Zimmermann (Reel) and Heather Norris Nicholson (Amateur; No) and archivists like David Cleveland. These researchers appreciated the personal 
view of history that these filmic records provided and suggested that amateur film production offered a valuable alternative to the official records of church and state.

Although nonprofessional production has been the subject of international research for several decades there have been few studies exploring the topic in Ireland. Notable exceptions include the work of Ciara Chambers ("Capturing"; "Spence") looking at the Northern Ireland amateur scene, the University College Cork/IFI research project Capturing the Nation: Irish Home Movies, 1930-1970 and resulting publication (Rascaroli, Young, and Monahan), and Sunniva O'Flynn's writing about the phenomenon of amateur films made by clergy within the IFI Archive collections. ${ }^{10}$

The role of women in amateur production is an emerging topic of international academic consideration, with one of the most interesting explorations of this area being the Film Archive UK's (FAUK) commissioned 2020 report by Stephanie Clayton, Melanie Williams, and Keith M. Johnston titled Invisible Innovators. Developed from a collaborative project between the University of East Anglia (UEA) and the East Anglian Film Archive, Invisible Innovators examines national and regional film collections across the UK, seeking to identify material of note and understand the reasons for female underrepresentation in the amateur realm. In an article exploring the original UEA project, Sarah Hill and Keith M. Johnston posit that the lack of regard for the work of female professional filmmakers is further compounded within the amateur field, citing Patricia Zimmerman's view that this form of filmmaking is often perceived as "simply an irrelevant pastime [...] defined by negation: nonprofessional, non-commercial, unnecessary" (1). They argue that women's amateur film is "doubly negated, existing at an overlap of archival oversight and cultural stigma" (2). The Invisible Innovators report is particularly useful in that it not only seeks to highlight the work of women amateur filmmakers but makes practical recommendations for ways other archives can emphasise female contributions through a range of exhibition and cataloguing strategies.

A recently published monograph by Annamaria Motrescu-Mayes and Heather Norris Nicholson, British Women Amateur Filmmakers, also seeks to understand and promote the work of female noncommercial filmmakers. The book examines the types of films women make, their creative motivation and interrogates the possible reasons for their lack of prominence. It suggests a complex network of factors have contributed to the absence of female authorship in UK film archives. In addition to recognising the obstacles that prevented women making films in the first place, such as a lack of confidence and personal agency, plus a deficit of financial resources and free time to indulge their interests, it finds that an absence of recognition for the endeavours of women within the amateur sphere is equally problematic. It suggests that women were active in the British Cine Society movement throughout the twentieth century and that there was a cohort of professional women who had access to film equipment and/or had enough free time to devote to this activity (teachers are cited as an example). However, the efforts of these women as cinematographers, editors, script writers and so forth were often attributed to their male colleagues, thus rendering their contribution invisible (Motrescu-Mayes and Norris Nicholson, 30-1).

In Ireland, there has been even less investigation into the work of female amateur filmmakers. Among the few researchers who have done so are Gwenda Young who touched upon the subject as part of the aforementioned Capturing the Nation project (88); researchers Edel Robinson and Sister Isabelle Smythe, who have explored work by female religious orders held in the IFI Irish Film Archive, such as the Holy Rosary Sisters and the Medical Missionaries of Mary; and Motrescu-Mayes and Norris Nicholson, who make reference to the $8 \mathrm{~mm}$ 
filmmaking activities of Northern Irish school teachers: a mother and daughter both called Grace Foster (137). ${ }^{11}$

Focusing on the collections of the IFI, it is difficult to assess the levels at which women are creatively represented in either the professional or nonprofessional collections due to an absence of adequate reporting mechanisms, something the IFI Archive is seeking to address by considering examples of best practice in peer institutions. The IFI Archive currently documents its collections using the International Federation of Film Archives cataloguing standard, as a result the metadata it records does not specifically indicate the gender of cast or crew. While this lack of data makes quantifying the level of gender disparity within the national film collection difficult, a superficial search of feature films in the IFI database indicates that over $20 \%$ of titles held were directed or codirected by women. This suggests that, while the area of commercial production may be male dominated (Barton 17), women creators are reasonably well represented in this part of the IFI collection. However, the same balance cannot be found in the amateur collections, where less than $8 \%$ of the amateur collections reflected in a database search were made totally or partially by women.

\section{Specific Collections}

While an extensive study of the number of works made by women filmmakers held by the IFI in the mode of the UEA/FAUK report is undoubtedly a worthwhile undertaking, and something that I would actively encourage, it is beyond the scope of this article. Therefore, I will concentrate on two amateur collections held by the IFI Archive that I feel warrant discussion, the films of Margaret Currivan and Overend Sisters. These collections are interesting examples of female authorship, providing a valuable insight into the lives of their creators, who in both cases enjoyed a level of financial security that fostered an environment in which their artistic interests could be pursued. Affluence is a common denominator in many of the nonprofessional collections held within the IFI; the expense of filmmaking generally excluded those of lesser means from pursuing it as a pastime. As a result, the filmic glimpses of the lower and working classes that exist within the IFI collections have often been captured by those with more privilege. Despite the narrow class-specific experience depicted within these two collections, I feel they are worthy of examination not only because of their female provenance, but also the quality of their filmmaking. I hope that this brief study will prompt more in-depth analyses of women's contribution to the sphere of nonprofessional filmmaking in Ireland.

\section{Currivan Collection}

The Margaret Currivan (1923-1985, née Meagher) Collection comprises twenty-four edited rolls of $8 \mathrm{~mm}$ film that cover the period from 1954 to 1964. It was donated to the IFI Archive by Margaret's daughter Helen Redden in July 2007. Margaret and her husband P. J. (Patrick Joseph) were owners of Currivan's Photographic Service, Keeper Road, in the Dublin suburb of Crumlin, where they also lived. They advertised themselves as "the camera people" and in addition to her interest in photography, Margaret was an avid amateur filmmaker and a member of the Dublin Cine Club (Young 88).

The collection mainly focuses on family activities in the Currivan home, vacations, excursions and seasonal celebrations. Trips to the family holiday home in the seaside town of 
Rush, County Dublin and to see grandparents are supplemented by footage of the British Pharmaceutical Conference in 1956, school displays, scouting activities, visits to Dublin Zoo, and the wedding of family friends. As is a common within amateur films, the collection features extensive footage of the Currivan children over a ten-year period and the footage has taken on a degree of poignancy due to the fact that two of the three children are now deceased.

The collection is valuable not only as an example of female amateur filmmaking but also for its formal qualities. Currivan is an assured filmmaker with a strong sense of the domestic and familial within her output. She is also creatively ambitious, displaying a level of technical proficiency that is often absent in amateur works. Amongst the production mechanisms she employs are constructed animated titles, meticulous editing and the occasional use of scripted and unscripted voiceovers to explain the narrative. Elements of contemporary popular culture are illustrated through shots of Beatles albums, a Meccano set and a Rawhide outfit, and locations and dates are well documented in intertitles. Currivan's professionalism reveals the somewhat porous nature of the amateur/professional categorisation, hinting at the possibilities that may have transpired had she been afforded the opportunity to develop her filmmaking as a career.

Two titles that particularly stand out are Up the Canal (1962), in which an old man reminisces about the Dublin's Royal Canal and A Day to Remember (1962), where we experience the ritual of Holy Communion from a child's (her daughter Helen) point of view. They are a fascinating combination of personal reflection and structured filmmaking, as Currivan aims to give voice to the experience of her relatives through creative expression. Both films set themselves apart from the majority of amateur films in the IFI Archive collection due to their ambitious narrative form and a protagonist-focused approach to storytelling that is rarely evident outside commercial production.

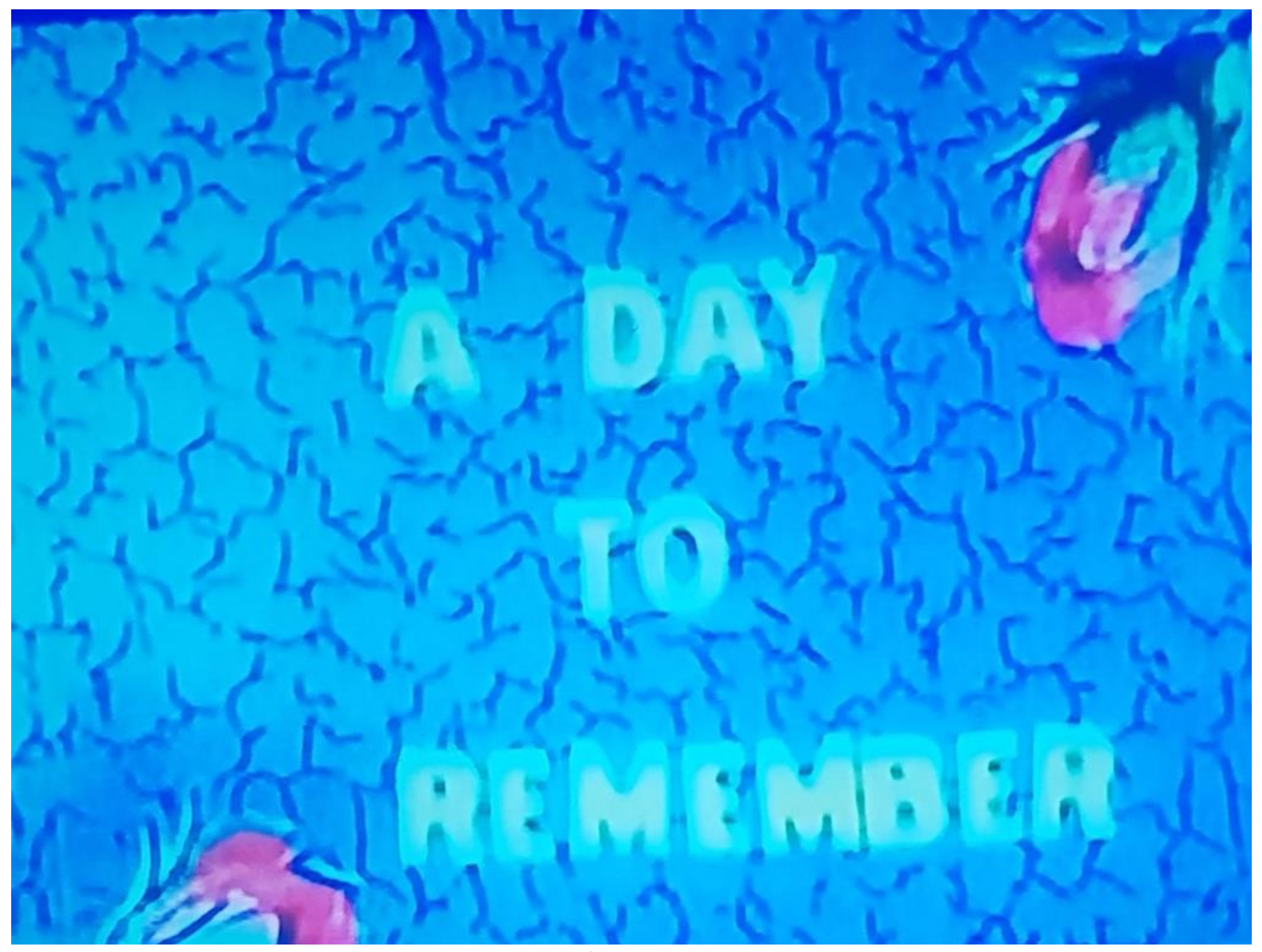

Figure: A Day to Remember (Margaret Currivan, 1962). Courtesy of the Irish Film Archive Currivan Collection. 


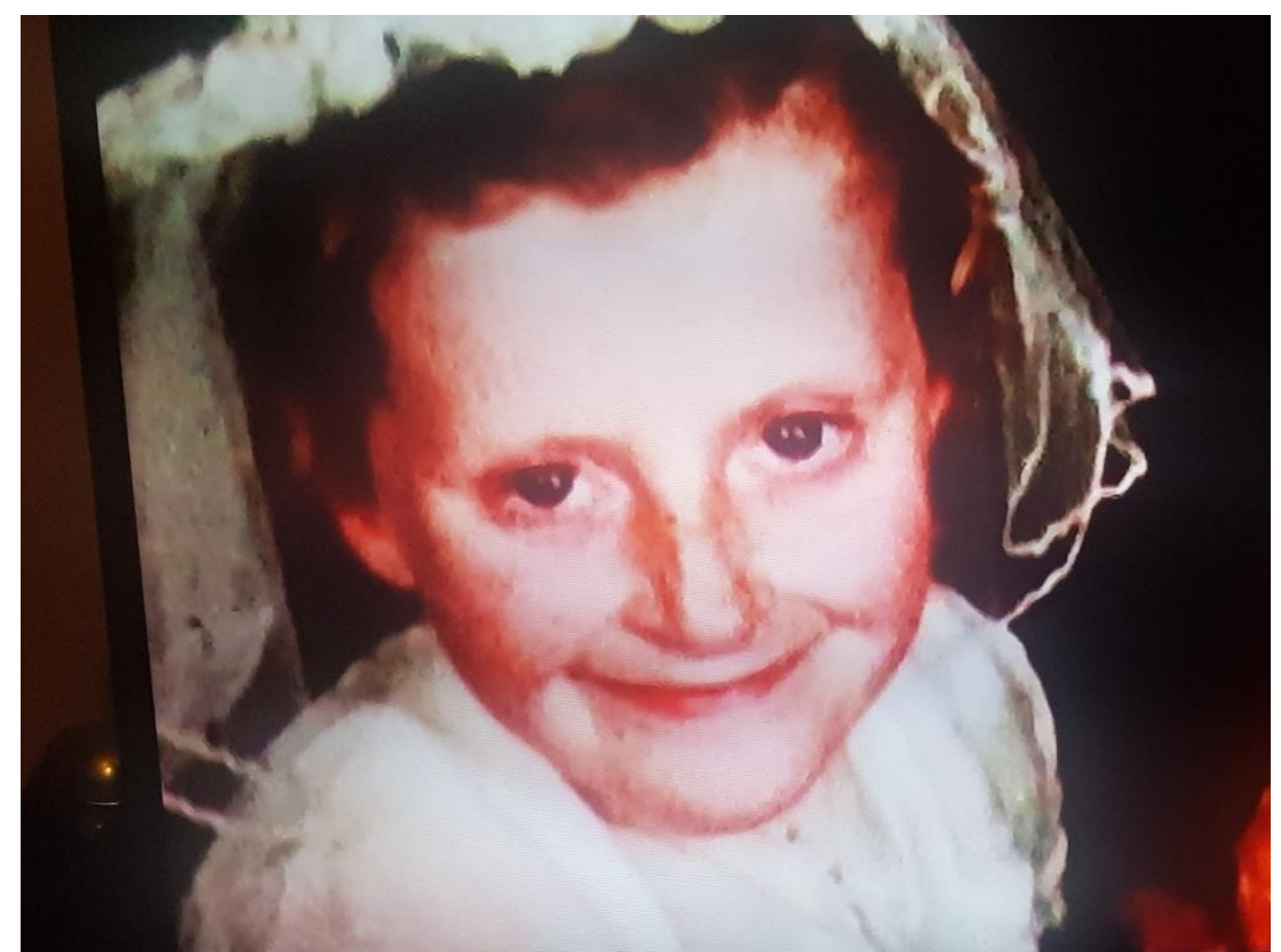

Figure 2: Margaret Currivan's daughter Helen from the film A Day to Remember (Margaret Currivan, 1962). Courtesy of the Irish Film Archive Currivan Collection.

Gwenda Young has remarked upon the homogeneity of amateur collections, citing the common focus on family events and holidays, as people seek to record the important milestones of their lives, as a factor (82). While these categories of interest are certainly reflected in Currivan's work, the proficiency of her technique and willingness to experiment with format and structure combined with a narrative sophistication elevate her films above traditional home movies. It could be argued that Currivan's affluence and the resources made available to her through the photographic business afforded her the time and equipment necessary to engage in filmmaking to an extent where she was able to achieve a level of technical skill. It is true that Currivan's position may be in contrast with many women in 1950s and 1960s Ireland, whose domestic responsibilities did not allow much space for extracurricular activities. Equally, amateur filmmaking was an expensive past-time requiring access to costly equipment, thus making it a hobby that was beyond the budget of most and confining it largely to the professional classes, clergy and wealthy. As professional people, the Currivans appear to have had access to the requisite time and equipment to indulge their filmmaking interests and the collection certainly portrays a comfortable mid-century family. However, the level of privilege captured is modest compared to that evident in another collection made by women: the Overend Collection.

\section{Overend Collection}

The Overend sisters Letitia (1880-1977) and Naomi (1900-1993) were daughters of a prominent Dublin solicitor, Trevor Overend, and his wife Lily (née Butler). In 1894, Trevor bought Airfield House and Estate in Dundrum where the sisters, who never married, resided for all of their lives. Both sisters entered into careers; Letitia became a member of the St. John's Ambulance Brigade in 1912, working there for thirty-five years, eventually becoming 
Superintendent in Chief, while Naomi trained as an accountant in order to oversee the running of the Estate. On her death in 1993, Naomi bequeathed the thirty-five-acre Estate to the Irish nation. It is now open to the public as Airfield House and Farm and administrated by the Airfield Trust who deposited the Overend film collection with the IFI Archive in 2009.

The Collection was filmed during the 1930s, 1940s and 1950s and comprises forty-one rolls of $16 \mathrm{~mm}$ film and three VHS tapes. The material sheds light on the life of this prosperous family, primarily reflecting the interests of the sisters. Despite an age difference of twenty years, Letitia and Naomi shared many past times including motorcars, gardening, cattle breeding and travel. They were also involved with charity work including the Irish War Hospital Supply Depot and were instrumental in the establishment of the Children's Sunshine Home in Stillorgan, County Dublin through their friendship with its founder Dr Ella Webb.

The collection consists principally of amateur travelogue footage, much of which features the family on holiday - frequently on-board cruise ships. A large portion of the collection is devoted to maritime activities, recreational and occupational, and features high seas locations and the Allied naval fleets just before the Second World War. The collection also reflects the sisters' interest in the British Royal family and includes four British Movietone newsreel films depicting events relating to George VI and a film of the Royal Guard at Buckingham Palace in 1939. Media interest in the Overend family is reflected in several profiles of the sisters made for television.

The collection features the most extensive number of foreign locations of any amateur collection held by the IFI. The Overend family undertook a world tour in 1935 and as a result, the films capture what would have then been considered exotic sights including the Acropolis in Athens, the Grand Canyon, Pyramids of Egypt, garlanded natives in Hawaii and hot springs of Iceland. Most of the films in this collection share the theme of transport, primarily by sea and much of the footage has a kinetic feel, having been filmed from moving vehicles (boats, motorcars, steam trains, trams and even a rickshaw) and from ships.

The second category within the Overend collection is of films depicting the sisters enjoying recreational activities at their home in Airfield. These include playing with pets in their beautifully tended gardens, posing with their Rolls Royce and their prize jersey herd and one section of film shows the sisters climbing a rock incline in their mature years. Less domestic activities are also captured such as lavish weddings, show jumping competitions and the sisters' humanitarian interest is reflected in a parade of the Knights of the Order of Malta filmed in the 1930s.

While the films in the Overend collection may not be as technically accomplished as those of Margaret Currivan, they provide a fascinating insight into the privileged world of work and leisure of this prominent Dublin family, whose elevated standing in society is evidenced by the naming of a road in their honour, Overend Way, Dundrum, Co. Dublin. While superficially the sisters captured similar domestic and recreational content to other nonprofessional filmmakers represented in the IFI Archive, in reality the subject matter in this collection is vastly different to most amateur films, mainly due to the elite world inhabited by its creators. The sisters' single status and affluence afforded them significant leisure time in which to indulge their personal interests, expanding their experience beyond the usual Irish home-movie depictions of regional holidays, children growing and family gatherings. Consequently, there are few films capturing new-born babies and children's birthday parties, so often seen in other collections and the Overend family holidays, unlike those of the 
Currivans, are not to Butlins and Rush, but to far more distant locales. While amateur filmmaking is said to portray a more democratic view of human experience than its professional counterpart (McNamara 41), the world depicted in the Overend collection is not that of the average Irish citizen, as it is filled with garden parties, chauffeurs, international travel and Rolls Royces, reflecting the high social standing and affluence of its authors.

\section{Reasons for Women's Underrepresentation}

While the Overend and Currivan collections provide an important counterbalance to the predominantly male viewpoint found in the IFI's noncommercial collections, the reasons why women's voices are largely absent from this sphere of filmmaking is something that requires further consideration. We have seen that the expense of amateur filmmaking and a shortage of personal time are two of the primary causes for women's limited contribution to nonprofessional production, resulting in their lack of representation within the IFI Archive collections. However, I would like to suggest a third reason for their absence in this sector: under-acknowledgment. While it is true that there is a deficit of female amateur filmmaking in the first instance, the dearth of women's work in the IFI collection is likely to have been compounded by a lack of recognition for the small number of works that were created and also by the mechanisms through which these works are acquired by the IFI. While most professional material comes into the IFI Archive via preservation contracts with the three state agencies that fund production, amateur productions tend to be put forward by the filmmakers themselves or their family members. Therefore, the films have already been subjected to a process of (self) assessment and selection regarding their social, artistic and historical value before reaching the IFI. It could be argued that women may not have confidence in their own abilities or value their output sufficiently to put material forward to be included in a national collection. An examination of the source of amateur material donated to the IFI Irish Film Archive indicates that, in most instances, women's amateur films have come into the archive via family members or third parties, while many male amateur collections have been put forward for preservation by the filmmaker himself. It is reasonable to hypothesise that, if women have not recognised the cultural and historic value of their own work, there may be interesting female amateur films that have not yet made their way into the IFI Archive and which could still be unearthed if a more supportive and appreciative climate for female creative output was fostered. This hypothesis corresponds with Motrescu-Mayes and Norris Nicholson's findings that women's role in amateur production in the UK has been largely under acknowledged: "like their paid contemporaries, amateur [women] practitioners assumed overlooked roles and responsibilities that have often been solely credited to men"; this includes "hidden contributions to scriptwriting, editing, sound, titling, continuity and other practical aspects of location and postproduction work" (31). Indeed, there may be many amateur films preserved within the IFI collections in which the role of women remains un- or under-acknowledged, mirroring the experience of our UK counterparts; further in-depth investigation would be required to reveal these hidden levels of activity.

While undertaking this research it has become evident to me that there are a number of practices the IFI Archive could commence in order to make women's contribution to the collections it holds more visible and to encourage the deposit of more female-led work. For example, a large-scale study similar to the Capturing the Nation project, which was a collaboration between the IFI and UCC, would be a timely and valuable contribution to Irish film research. Such a project to identify, digitise, catalogue and exhibit women's amateur work would be a costly and resource-intensive activity, however it is something the IFI is eager to 
undertake should the necessary funding and academic partner be secured. In the meantime, the IFI Archive is considering adopting some of the suggestions offered in the Invisible Innovators report commissioned by the Film Archives UK, of which the IFI Archive is an associate member. While not all of the report's suggestions are applicable in an Irish context, due to the difference in archival and funding landscapes between the UK and Ireland, the IFI is planning to review its access and cataloguing policies and procedures, as suggested by Invisible Innovators, in order to highlight women's contribution in all sectors of moving-image production.

\section{Conclusion}

It is clear that a recent cultural shift in Ireland has led to a demand for greater recognition and representation of women across many spheres of the arts. This is being acted upon in the film production sector through policy and funding, yet the area of nonprofessional filmmaking remains under-researched and under-supported. Although it has been suggested that the IFI needs to do more to acknowledge and promote women as practitioners (Healion et al., 168), it is evident that the organisation is now undertaking initiatives to address gender disparity. While most of the measures adopted thus far relate to professional production and programming, the IFI Archive is now looking to the work of the FAUK and others to help improve its approach to recording and promoting the contribution of women filmmakers. Although the role of female filmmakers in the IFI Archive collections may appear minimal at first glance, this article has attempted to excavate their important contribution in shaping the content of the IFI collections, specifically by highlighting two amateur collections made by women that are preserved by the organisation. I am hopeful that the introduction of new cataloguing and exhibition initiatives, alongside the existing strategies outlined in this article, will help to improve gender representation in the IFI and IFI Archive and raise awareness of the rich diversity of female led content within the national moving-image collection.

\section{Notes}

${ }^{1}$ The Irish Film Institute is Ireland's national cultural institution for film with a remit to Exhibit, Preserve and Educate. The IFI Archive holds Ireland's national moving image collection spanning 1897 to the present day.

${ }^{2}$ For the purposes of this piece, the terms "amateur", "noncommercial" and "nonprofessional" will be used interchangeably.

${ }^{3}$ My dissertation, Inghinidhe Ealaine na hEireann, was submitted in December 1998.

${ }^{4}$ Sheila Pratschke was Director of the IFI from 1994 until 2000. Martha O'Neill was Chair of the IFI Board from 1997 to 2002.

${ }^{5}$ Irish National Cultural Institutions named in the 1997 Cultural Institutions Act led by women are the National Archives of Ireland, dir. Orlaith McBride; The National Library of Ireland, dir. Sandra Collins; The National Museum of Ireland, dir. Lynn Scarfe; The Chester Beatty Library, dir. Fionnuala Croke; The Irish Museum of Modern Art, dir. Annie Fletcher; and the 
Crawford Art Gallery, dir. Mary McCarthy. Women leading state arts funding agencies are Desiree Finnegan at Screen Ireland, Maureen Kennelly at the Arts Council, Virginia Teehan at The Heritage Council, and Tania Banotti at Culture Ireland.

${ }^{6}$ Festivals that signed the pledge are Animation Dingle, Cork Film Festival, Dublin Feminist Film Festival, Galway Film Fleadh, Gaze LGBT Film Festival, Kerry Film Festival, Still Voices Short Film Festival and Virgin Media Dublin International Film Festival.

${ }^{7}$ The F-Rating was launched at the Bath Film Festival in 2014, as a mechanism to indicate a film title where women are significantly involved. The IFI F-Rating indicates a female writer or director. The next major IFI Archive preservation project will focus on work by Margo Harkin, Trish McAdam and Anne Crilly. A programme of shorts made by women will be published on the IFI Player in 2021.

${ }^{8}$ Comment by Head of Irish Film Programming at Spotlight 2020.

${ }^{9}$ Screen Ireland is the state agency for film television and animation and is funded by the Department of Culture and Heritage. The BAI is the regulator of the public and commercial broadcasting sector, but also funds radio, television and film production via the television licence fee. The Arts Council is the national agency for funding, developing and promoting the arts in Ireland; it is funded through the Department of Tourism, Culture, Arts, Gaeltacht, Sport and Media, funding production via various schemes.

${ }^{10}$ Capturing the Nation was a collaborative project between University College Cork and the Irish Film Institute examining Irish amateur film production between 1930 and 1970. It was funded by the Irish Research Council for the Humanities and Social Sciences.

${ }^{11}$ Both women have presented often on this topic; Robinson is currently undertaking $\mathrm{PhD}$ research on the subject at Birkbeck, University of London.

\section{References}

Advancing Gender Equality in Decision-Making in Media Organisations: Main Findings. European Institute for Gender Equality, 24 Oct. 2013, eige.europa.eu/publications/advancing-gender-equality-decision-making-mediaorganisations-report.

Barton, Ruth. "A Female Voice in Irish Cinema: Women Filmmakers and the Creative Documentary." New Hibernia Review, Center for Irish Studies at the University of St. Thomas, vol. 21, no. 2, Summer/Samhreadh, 2017, pp. 17-32, DOI: https://doi.org/10.1353/nhr.2017.0013.

---. "Irish Cinema and the Gendering of Space: Motherhood, Domesticity and the Homeplace." Liddy, Women, pp. 233-48.

Bean, Jennifer M., and Diane Negra. A Feminist Reader in Early Cinema, Duke UP, 2002. 
Broadcasting Authority of Ireland. "More than $€ 7 \mathrm{~m}$ Allocated to 126 Projects under BAI's Sound \& Vision Scheme." 3 Apr. 2020, www.bai.ie/en/more-than-e7m-allocated-to126-projects-under-bais-sound-vision-scheme.

Casella, Donna R. "Women and Nationalism in Indigenous Irish Filmmaking of the Silent Period." Researching Women in Silent Cinema: New Findings and Perspectives, edited by Monica Dall'Asta, Victoria Duckett, and Lucia Tralli, University of Bologna, 2013, pp. 253-80.

Chambers, Ciara. "Capturing Ireland: The Travelogues of J. J. Tohill." Tourists \& Nomads: Amateur Images of Migration, edited by Sonja Kmec and Viviane Thill, Jonas Verlag, 2012, pp. 57-65.

---. "The Spence Brothers: Amateur Sci-Fi and Cine Culture in Northern Ireland." Small Gauge Storytelling: Discovering the Amateur Fiction Film, edited by Ryan Shand and Ian Craven, Edinburgh UP, 2013, pp. 278-97.

Clayton, Stephanie, Keith M. Johnson, and Melanie Williams. Invisible Innovators: Making Women Filmmakers Visible Across the UK Film Archives. University of East Anglia and Film Archives UK, 2019, www.filmarchives.org.uk/wpcontent/uploads/2020/03/Invisible-Innovators.pdf.

Cleveland, David. Films Were Made: A Look at Films and Filmmakers in the East of England 1896-1996. University of East Anglia, 2009.

Connolly, Maeve. “Choreographing Women's Work: Multitaskers, Smartphone Users and Virtuoso Performers." Women Artists, Feminism, and the Moving Image: Contexts and Practices, edited by Lucy Reynolds, Bloomsbury, 2019, pp. 215-27.

---. "Feminism, Ireland and Women's Video Art." European Women's Video Art, edited by Laura Leuzzi, Elaine Shemilt, and Stephen Patridge, John Libbey Publishing, 2019, pp. 139-56.

---. "Women Cinematographers and Changing Irish Production Cultures.” Liddy, Women, pp. 83-98.

A Day to Remember. Dir. Margaret Currivan, IFI Irish Film Archive Collection, 1962.

Equality, Human Rights \& Diversity Policy \& Strategy. Arts Council of Ireland, 2019, www.artscouncil.ie/uploadedFiles/EHRD Policy English version Final.pdf.

Gaines, Jane. Pink-Slipped: What Happened to Women in the Silent Film Industries? U of Illinois P, 2018.

Gender Action Plan. Broadcasting Authority of Ireland, Apr. 2018, www.bai.ie/en/media/sites/2/dlm_uploads/2018/04/20180423_BAI_GenderActionPla n_vFinal_AR.pdf.

Gender Data Chart. The Organisation for Economic Co-operation and Development (OECD), 2018, www.oecd.org/gender/data/employment. 
Gender Pay Gap Research Report. The Community Foundation for Ireland, 2018, www.communityfoundation.ie/insights/news/gender-pay-gap-research.

Gledhill, Christine. "Film Culture." Screen, vol. 16, no. 3, Autumn 1975, pp. 107-28, DOI: https://doi.org/10.1093/screen/16.3.107.

Gledhill, Christine, and Julia Knight, editors. Doing Women's Film History: Reframing Cinemas, Past and Future (Women \& Film History International). U of Illinois P, 2015.

Healion, Karla, et al. "Activism through Celebration, the Role of the Dublin Feminist Film Festival in Supporting Irish Film 2014-17." Liddy, Women, pp. 153-68.

Hill, Sarah, and Keith M. Johnston. "Making Women Amateur Filmmakers Visible: Reclaiming Women's Work through the Film Archive." Women's History Review, vol. 29, no. 5, 2020, pp. 875-89, DOI: https://doi.org/10.1080/09612025.2019.1703541.

Irish Film Institute website. www.ifi.ie. Accessed 20 July 2020.

Keating, Sara. "Abbey Director 'Regrets Exclusions' in Programme: Fiach Mac Conghail Says Reaction Sparked 'a professional and personal crisis'.” Irish Times, 6 Nov. 2015, www.irishtimes.com/culture/stage/abbey-director-regrets-exclusions-in-programme1.2419782 .

Liddy, Susan. "Missing in Action: Where are the Irish Women Screenwriters?" Film Ireland, 20 Apr. 2015, filmireland.net/2015/04/20/missing-in-action-where-are-the-irishwomen-screenwriters.

---. "'Open to all and everybody?' The Irish Film Board: Accounting for the Scarcity of Women Screenwriters." Feminist Media Studies, vol. 16, no. 5, 2016, pp. 901-17, DOI: https://doi.org/10.1080/14680777.2015.1137961.

---. "Setting the Scene: Women in the Irish Film Industry." Liddy, Women, pp. 1-14.

---. "Where are the women'? Exploring Perceptions of a Gender Order in the Irish Film Industry." Liddy, Women, pp. 51-66.

---. "Women and the Irish film Industry." Letter to the Irish Times, 11 Nov. 2015, www.irishtimes.com/opinion/letters/women-and-the-irish-film-industry-1.2424444.

---, editor. Women in Irish Film: Stories and Storytellers. Cork UP, 2020.

MacNamara, Peter. “Amateur Film as Historical Record: A Democratic History?”, Journal of Film Preservation, vol. 25, no. 53, Nov. 1996, pp. 41-5.

Motrescu-Mayes, Annamaria, and Heather Norris Nicholson. British Women Amateur Filmmakers: National Memories and Global Identities. Edinburgh UP, 2018.

Mullally, Una. "Abbey Theatre Celebrates 1916 Centenary with only One-woman Playwright", Irish Times, 2 Nov. 2015, www.irishtimes.com/opinion/una-mullally-abbey-theatrecelebrates-1916-centenary-with-only-one-woman-playwright-1.2413277. 
Norris Nicholson, Heather. Amateur Film: Meaning and Practice, 1927-1977, Manchester UP, 2012.

"Everyday Life and Other Stories: The Visual Practices of Britain's Amateur Filmmakers Some Preliminary Findings." Abenteuer Alltag: Zur Archäologie des Amateurfilms, edited by Siegfried Mattl et al., Columbia UP, 2015. pp. 199-217.

No Small Change: Closing the Gender Pay Gap. National Women's Council Ireland, 23 Nov. 2017,www.nwci.ie/learn/publication/no_small_change_closing_the_gender_pay_gap.

O’Brien, Anne. "Documenting Documentary: Liberated Enclave or Pink Ghetto." Liddy, Women, pp. 117-32.

---. “Feminine or Feminist? Women's Media Leadership.” Feminist Media Studies, vol. 17, no. 6, 2017, pp. 836-50, DOI: https://doi.org/10.1080/14680777.2017.1300593.

---. “'Men own television': Why Women Leave Media Work.” Media, Culture \& Society, vol. 36, no. 8, 2014, pp. 1207-18, DOI: https://doi.org/10.1177/0163443714544868.

---. "Producing Television and Reproducing Gender." Television \& New Media, vol. 16, no. 3, 2015, pp. 259-74, DOI: https://doi.org/10.1177/1527476414557952.

---. Women, Inequality and Media Work. Routledge, 2019.

O'Flynn, Sunniva. "Black and White and Collar Films: Exploring the Irish Film Archive of Clerical Collections." Keeping It Real: Irish Film and Television, edited by Ruth Barton and Harvey O'Brien, Wallflower Press, 2004, pp. 39-51.

Rascaroli, Laura, Gwenda Young, and Barry Monahan, editors. Amateur Filmmaking: The Home Movie, the Archive and the Web. Bloomsbury, 2014.

"Six Point Plan on Gender Equality." Screen Ireland, 2015, www.screenireland.ie/about/gender.

Smith, Adrian. "How Sounding the Feminists Put Music and Gender in the Spotlight." Journal of Music, 11 Apr. 2019. journalofmusic.com/focus/how-sounding-feminists-put-musicand-gender-spotlight.

Stamp, Shelley. Lois Weber in Early Hollywood. U of California P, 2015.

Topaz, Chad M., et al. "Diversity of Artists in Major U.S. Museums." PLoS ONE, vol. 6, no. 3, 20 March 2019, , DOI: https://doi.org/10.1371/journal.pone.0212852.

“2019 Gender Statistics for Development and Production Applications.” Screen Ireland, 2019, www.screenireland.ie/images/uploads/general/2019_Gender_Stats_Production_Devel opment.pdf. Accessed 15 July 2020.

Up the Canal. Dir. Margaret Currivan, IFI Irish Film Archive Collection, 1962. 
Young, Gwenda. "Glimpses of a Hidden History: Exploring Irish Amateur Collection, 193070." Amateur Filmmaking: The Home Movie, the Archive and the Web, edited by Laura Rascaroli, Gwenda Young, and Barry Monahan, Bloomsbury, 2014, pp. 81-95.

Zimmermann, Patricia R. Reel Families: A Social History of Amateur Film. Indiana UP, 1995.

---. "Introduction. The Home Movie Movement: Excavations, Artifacts, Minings." Mining the Home Movie: Excavations in Histories and Memories, edited by Karen L. Ishizuka and Patricia R. Zimmermann, U of California P, 2008, pp. 1-28.

\section{Suggested Citation}

O'Connell, Kasandra. "Archivally Absent? Female Filmmakers in the IFI Irish Film Archive." Alphaville: Journal of Film and Screen Media, no. 20, 2020, pp. 12-27, DOI: https://doi.org/10.33178/alpha.20.02.

Kasandra O'Connell has a postgraduate qualification in Archival Science, an MA in Museum Studies and is currently undertaking $\mathrm{PhD}$ research in moving image preservation and policy at Dublin City University. She has written about digital preservation and moving image archiving for a number of publications including Film Ireland, History Ireland, Journal of the Society of Archivists and the International Journal of Film Preservation and is a member of the editorial board of The Moving Image Journal. She has been Head of the IFI Irish Film Archive since 2000 . 